\title{
Neurogenic tumours of the mediastinum: A report of 60 cases
}

\author{
Salih Topçu MD, Aysin Alper MD, Erkmen Gülhan MD, \\ Osman Koçyigit MD, Irfan Tastepe MD, Güven Çetin MD, \\ Atatürk Chest Disease and Chest Surgery Centre, Department of Chest Surgery, \\ Ankara, Turkey
}

S Topçu, A Alper, E Gülhan, O Koçyigit, I Tastepe, G Çetin. Neurogenic tumours of the mediastinum: A report of 60 cases. Can Respir J 2000;7(3):261-265.

OBJECTIVES: To analyze retrospectively 60 patients (13 infants and children, 47 adults -21 men and 39 women) with mediastinal neurogenic tumours admitted to Atatürk Centre for Chest Disease and Chest Surgery, Ankara, Turkey between 1988 and 1999. This comprised $21.2 \%$ of 283 patients who had surgical operations for all mediastinal masses during the same period.

PATIENTS AND METHODS: The patients ranged from four to 67 years of age. Thirteen patients were younger than 15 years and 47 were 15 years of age or older. Medical records were reviewed for demographic data, clinical presentation, diagnostic investigations, operative procedures, and tumour location and invasion. Postoperative morbidity and mortality were noted as well as long term follow-up. The clinical investigations included chest $\mathrm{x}$-ray and computed tomography of the thorax in all patients, and spinal magnetic resonance imaging and bronchoscopical examination in some. Clinical variables were compared.

RESULTS: The tumours had the following characteristics: $42(70 \%)$ were nerve sheath tumours; 15 (25\%) were autonomic ganglion tumours; two $(3.6 \%)$ were paragangliomas; and one $(1.4 \%)$ was a malignant peripheral neuroectodermal tumour (Askin's tumour). Nerve cell tumours comprised the majority of tumours in infants and children (nine of 13, 69\%), whereas the nerve sheath tumours were most frequent in adults ( 39 of $47,83 \%$ ). There were 48 benign and $12(20 \%)$ malignant tumours when all age groups were considered; the malignancy rate was $61.5 \%$ (eight of 13 ) in children and $8.5 \%$ (four of $47, \mathrm{P}<0.05$ ) in adults. All patients were operated via a posterolateral thoracotomy. Surgical resection of the tumour was complete in 56 of 60 patients $(93.3 \%)$. Resection of malignant tumours was grossly incomplete in four cases (four of 12,33.3\%). All benign tumours were totally excised. There were two major complications (respiratory failure and pulmonary emboli) and 14 minor complications in the perioperative period. The mean follow-up period was five years and seven months. Tumours recurred in $5.3 \%$ (three of 56) of patients who had a complete resection initially. There were no late deaths related to benign tumours.

CONCLUSIONS: Complete resection of tumours can be performed safely by a thoracotomy approach and is important for achieving satisfactory long term survival in most mediastinal neurogenic tumours.

Key Words: Mediastinal masses; Mediastinum; Neurogenic tumours; Surgical treatment 


\section{Tumeurs neurogènes du médiastin : rapport sur 600 cas}

OBJECTIF : Effectuer une analyse rétrospective du dossier médical de 60 patients (13 enfants et 47 adultes : 21 hommes et 39 femmes) admis à l'hôpital Atatürk Centre for Chest Disease and Chest Surgery, à Ankara, en Turquie, entre 1988 et 1999, pour tumeur neurogène du médiastin. L'étude porte également sur $21,2 \%$ des 283 patients qui ont été opérés pour tout genre de masses médiastinales durant la même période.

PATIENTS ET MÉTHODE : L'âge des patients variait de 4 à 67 ans; treize d'entre eux avaient moins de 15 ans et 47 avaient 15 ans et plus. On a passé en revue les dossiers médicaux à la recherche des renseignements suivants : données démographiques, tableau clinique, diagnostic, investigation, interventions chirurgicales, siège de la tumeur et degré d'envahissement. Ont aussi été notés la morbidité et la mortalité postopératoires ainsi que le suivi à long terme. L'investigation clinique comprenait une radiographie thoracique et une tomodensitométrie du thorax effectuées chez tous les patients, auxquelles s'ajoutaient une exploration de la colonne vertébrale à l'aide de l'imagerie par résonance magnétique et une bronchoscopie pratiquées chez certains d'entre eux. Il y a eu comparaison des variables cliniques. RÉSULTATS : Les tumeurs présentaient les caractéristiques suivantes : $42(70 \%)$ touchaient la gaine nerveuse; $15(25 \%)$, les ganglions sympathiques; $2(3,6 \%)$, les paraganglions, et $1(1,4 \%)$, de nature maligne, le neuroectoderme périphérique (tumeur d'Askin). Les tumeurs des cellules nerveuses se trouvaient surtout chez les enfants ( 9 sur 13; $69 \%$ ), tandis que les tumeurs de la gaine nerveuse étaient plus fréquentes chez les adultes (39 sur 47; $83 \%)$. On a compté 48 cas de tumeur bénigne et 12 (20\%) cas de tumeur maligne, tous groupes confondus; le taux de tumeur maligne s'établissait à $61,5 \%$ (8 sur 13) chez les enfants et à 8,5\% (4 sur 47; $\mathrm{P}<0,05)$ chez les adultes. Tous les patients ont subi une opération par thoracotomie postéro-latérale. Il y a eu résection complète de la tumeur chez 56 des 60 patients $(93,3 \%)$ et résection nettement incomplète de tumeurs malignes dans quatre cas ( 4 sur 12; 33,3\%). Toutes les tumeurs bénignes ont été complètement excisées. Il y eu deux cas de complications sérieuses (insuffisance respiratoire et embolie pulmonaire) et quatorze cas de complications peu graves durant la phase périopératoire. Le suivi a duré en moyenne cinq ans et sept mois. Les tumeurs sont réapparues dans $5,3 \%$ (3 sur 56) des cas où il y avait déjà eu résection complète. On n'a relevé aucune mort tardive liée aux tumeurs bénignes.

CONCLUSION : La résection complète des tumeurs neurogènes du médiastin est possible par thoracotomie, et ce, en toute sécurité, et il est important de les exciser en tout pour permettre la survie à long terme de la plupart des patients.
$\mathrm{M}$

ediastinal neurogenic tumours (MNT) account for approximately $20 \%$ of all adult, and $35 \%$ of all pediatric, mediastinal neoplasms (1-3). They are the most common cause of posterior mediastinal masses. Approximately $90 \%$ of these tumours occur in the posterior mediastinum or paravertebral sulcus. Mediastinal neurogenic tumours are benign in most cases, with an overall incidence of malignancy ranging from $3 \%$ to $19 \%(1,4,5)$. Surgical resection is considered the primary treatment of such tumours and is usually performed through a thoracotomy $(2,6)$.

In the present paper, a 10-year experience with MNT was reviewed, which dealt with the clinical manifestations, diagnostic problems and surgical treatment of these tumours in our clinics.

\section{PATIENTS AND METHODS}

The study comprised 60 patients (39 females, 21 males) who underwent resective surgery for MNT at Atatürk Centre for Chest Disease and Chest Surgery, Ankara, Turkey between 1988 and 1999. This comprised 21.2\% of 283 patients who had surgical operations for all mediastinal masses during the same period. The age of the patients ranged from four to 67 years of age (mean 29.2 years). Thirteen patients were younger than 15 years of age (mean age six years, with girls averaging nine years and boys averaging four years). Forty-seven patients were 15 years of age or older (mean age 47, with the averge age for women 30 years and that for men 17 years). Medical records were reviewed for demographic data, clinical presentation, diagnostic investigations, operative procedures, and tumour location and invasion as determined by the surgeon. Postoperative morbidity and mortality were noted as well as long term follow-up. If the patients had died, additional information was obtained from death certificates and autopsy records.
Patients in whom insufficiant histological data were available to confirm the diagnosis were excluded. The clinical investigations included chest $\mathrm{x}$-ray and computed tomography $(\mathrm{CT})$ of the thorax in all patients, and spinal magnetic resonance imaging (MRI) in eight patients. Fifteen of the patients underwent bronchoscopical examination. The mean follow-up period was five years and seven months (range six months to seven years). Clinical variables were performed using the Student's $t$ test .

\section{RESULTS}

Tumour histology: The histopathological diagnosis of the tumours in 60 patients included $42(70 \%)$ nerve sheath tumours (28 benign schwannomas, 11 neurofibromas and three malignant schwannomas), 15 (25\%) autonomic ganglion tumours (seven ganglioneuromas, five ganglioneuroblastomas and three neuroblastomas), two paragangliomas $(3.6 \%)$ and one (1.3\%) malignant peripheral neuroectodermal tumour (Askin's tumour). In three patients (5\%), the tumours were associated with von Recklinghausen's disease and these included two neurofibromas $(18.1 \%$ of all neurofibromas) and one malignant schwannoma. The pathological types and behaviours of the tumours by age group are shown in Table 1. Nerve cell tumours were the majority (nine of 13, $69 \%$ ) in infants and children, whereas the nerve sheath tumours were most common ( 39 of $47,83 \%$ ) in adults. There were 48 benign and 12 malignant (20\%) tumours when all age groups were considered. The malignancy rate was $61.5 \%$ (eight of 13 ) in children and $8.5 \%$ (four of $47, \mathrm{P}<0.05$ ) in adults. The malignant tumours consisted of three neuroblastomas, three ganglioneuroblastomas, one malignant schwannoma and one Askin's tumour in children, and two malignant schwannomas and two ganglioneuroblastomas in adults. In children, malignancy was more frequent in boys (three of 
TABLE 1

Tumour type and behaviour in children and adult patients with mediastinal neurogenic tumours

\begin{tabular}{lccc}
\hline & $\begin{array}{c}\text { Children* }^{*}(\mathbf{n = 1 3 )} \\
\text { Tumour type }\end{array}$ & $\begin{array}{c}\text { Adults }^{\dagger} \\
(\mathbf{n}=\mathbf{4 7})\end{array}$ & $\begin{array}{c}\text { Total } \\
(\mathbf{n}=60)\end{array}$ \\
\hline Nerve sheath tumours & $3(23 \%)$ & $39(83 \%)$ & $42(70 \%)$ \\
$\quad$ Benign schwannoma & 1 & 27 & 28 \\
$\quad$ Malignant schwannoma & 1 & 2 & 3 \\
$\quad$ Neurofibroma & 1 & 10 & 11 \\
Autonomic ganglion tumours & $9(69 \%)$ & $6(13 \%)$ & $15(25 \%)$ \\
$\quad$ Neuroblastoma & 3 & - & 3 \\
$\quad$ Ganglioneuroblastoma & 3 & 2 & 5 \\
$\quad$ Ganglioneuroma & 3 & 4 & 7 \\
Paraganglioma & $-(0 \%)$ & $2(4 \%)$ & $2(3.6 \%)$ \\
Askin's tumour & $1(8 \%)$ & $-(0 \%)$ & $1(1.4 \%)$ \\
Tumour behaviour & & & \\
Benign & 5 & 43 & 48 \\
Malignant & $8(61.5 \%)$ & $(8.5 \%)$ & $12(20 \%)$ \\
\hline
\end{tabular}

*Zero to 14 years of age; ${ }^{\dagger}$ Older than 14 years of age

four, $75 \%$ ) than in girls (five of nine, $55 \%, \mathrm{P}<0.05$ ). In adults, the frequency of malignancy was almost equally divided (two of 30 women, $6.6 \%$, and one of 17 men, $5.8 \%$ ).

Signs and symptoms: Forty-three patients $(71 \%)$ were symptomatic. Respiratory symptoms (cough or dyspnea) were the most common complaints $(n=32)$. The other symptoms, in decreasing order were chest pain $(n=17)$, malaise $(n=8)$, dysphagia $(n=3)$ and others $(n=8)$. The results of a physical examination were normal in 24 patients. The most common signs of distress were respiratory (including rales, dullness to percussion, tenderness and wheezing), which were seen in 22 patients. Three patients with neurofibromatosis had café-au-lait spots and subcutaneous nodules.

Diagnostic investigations: All patients underwent chest radiography and $\mathrm{CT}$ of the thorax as an initial diagnostic study (Figure 1). Spinal MRI was obtained in eight patients. Most tumours $(\mathrm{n}=58,96.6 \%)$ were located in the posterior mediastinum, whereas two were found in the middle mediastinum. Among the 15 patients who underwent bronchoscopic examination, bronchial compression was detected in three cases.

Surgical approach: All patients were operated via a posterolateral thoracotomy. Surgical resection of the tumour was complete in 56 of 60 patients (93.3\%). Resection of malignant tumours was grossly incomplete in four of 12 patients $(33.3 \%)$. This group of tumours consisted of one malignant schwannoma, one ganglioneuroblastoma (with abdominal metastasis), one neuroblastoma and one Askin's tumour. All benign tumours were excised totally. Two of the ganglioneuromas and one of the malignant schwannomas had spinal cord invasion. Laminectomy was carried out by neurosurgeons in these patients. There were two major complications (one pulmunary emboli and one respiratory failure) and 17 minor complications (nine pulmonary complications including pneumothorax, pneumonia and atelectasis, four wound infections, two recurrent laryngeal nerve paralysis, one elevated diaphragm and one Horner's syndrome) in the perioperative

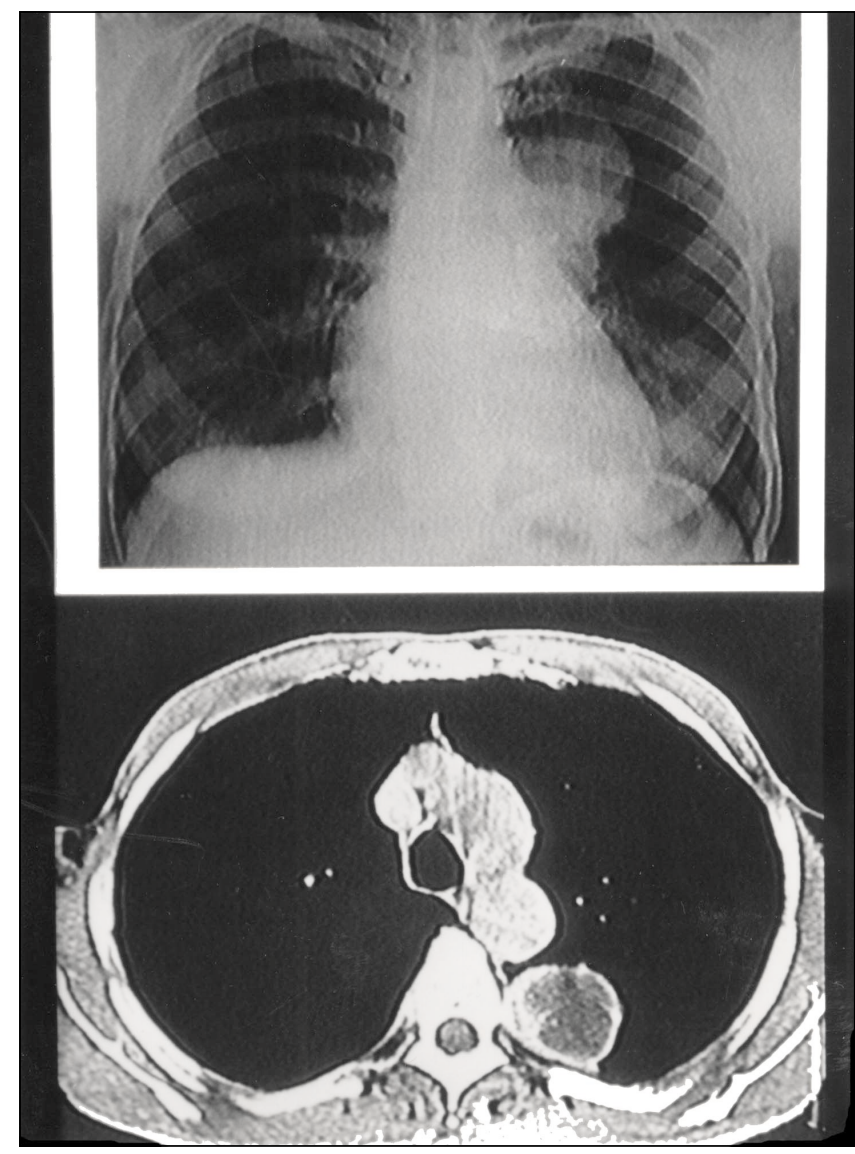

Figure 1) The chest $x$-ray (top) and computed tomography (bottom) of a totally excised schwannoma, shown as a well-defined paravertebral mass

period. There were two perioperative deaths. One patient with neuroblastoma died of respiratory failure on the first postoperative day, and another patient with neurofibroma died of pulmunary emboli on the sixth postoperative day.

Follow-up: The mean follow-up period was five years and seven months (range six months to seven years). Tumours recurred in three of 56 patients $(5.3 \%)$ who had a complete resection initially. Two of the patients with recurrence had neurofibromatosis; the patient with recurrence at six months underwent resectional surgery with rethoracotomy, and the other patient with recurrence at one year had surgical excision with median sternotomy. The third patient had malignant schwannoma and the recurrence was detected three years after the first operation; his lesion in the axillary region was removed successfully. Postoperative adjuvant therapy included chemotherapy for one patient with Askin's tumour (Figure 2), radiotherapy for two patients with malignant schwannoma and chemotherapy plus radiotherapy for one patient with ganglioneuroblastoma.

In the follow-up period, one patient with malignant schwannoma died because of myocardial infarction during the radiotherapy in the sixth month, and the patient with the Askin's tumour died of respiratory failure in the second year after the operation. There were no late deaths related to benign tumours. 


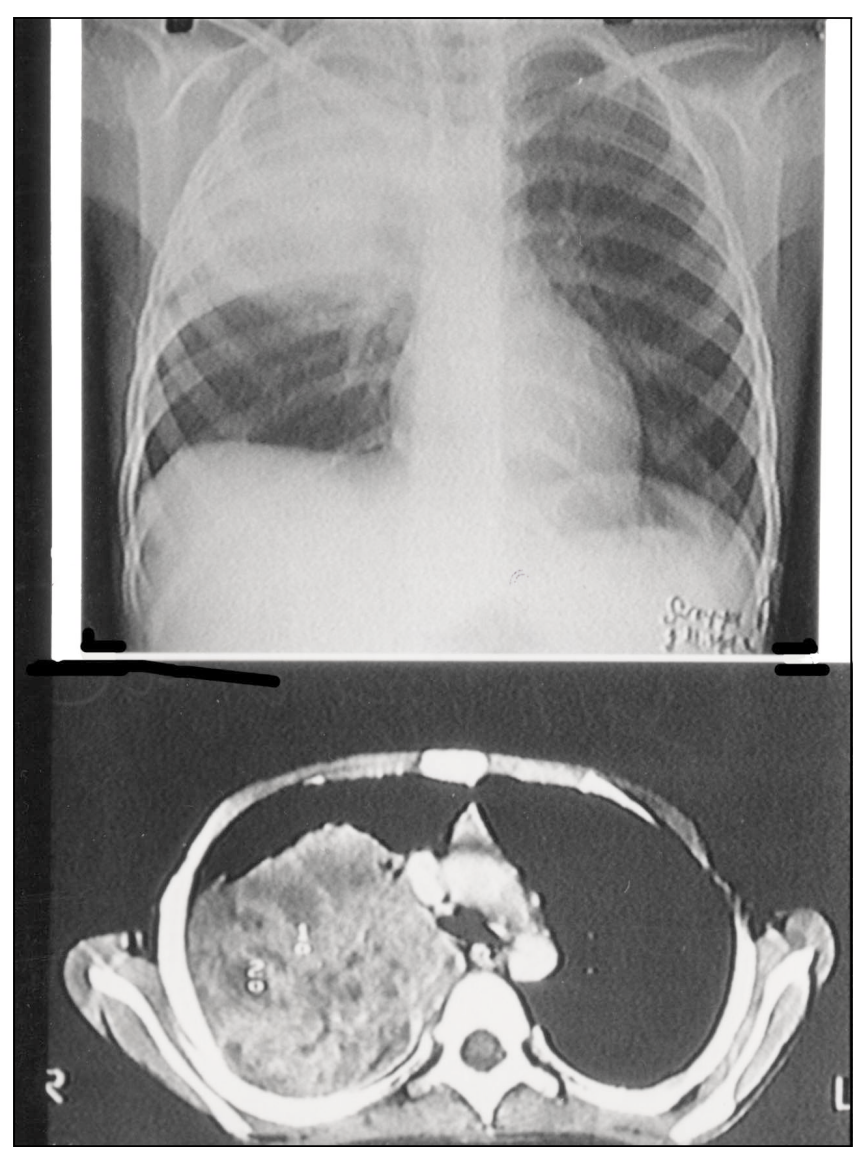

Figure 2) The chest $x$-ray (top) and computed tomography (bottom), in a seven-year-old girl, of a large, lobulated mass lesion in the right upper zone that was subtotally excised via right thoracotomy. Given the diagnosis of the Askin's tumour, the patient received chemotherapy postoperatively, but died in the second postoperative year

\section{DISCUSSION}

Neurogenic tumours comprise approximately $19 \%$ to $39 \%$ of all mediastinal tumours (1-7). They are the most common type of posterior mediastinal tumours. In our practice, they comprised $21.2 \%$ of all mediastinal tumours in patients from all age groups who had surgical operations for mediastinal masses. Neurogenic tumours are generally grouped into three major catogories: those arising from peripheral nerves (nerve sheath tumours); those arising from autonomic ganglia (nerve cell tumours); and, rarely, those arising from the paraganglionic system (paragangliomas) (8). Nerve sheath tumours are most common in adults, while nerve cell tumours are more common in children $(8,9)$. These previous reports were consistent with our findings that nerve cell tumours comprised the majority in children (69\%), and nerve sheath tumours were more common in adults (83\%). When all age groups were considered, the schwannomas constituted the largest group with a frequency of 51.6\%; other studies report the incidence of schwannomas as between $45 \%$ and $60 \%(2,8)$. In previous studies, the mediastinal tumours have been benign in most instances, with an overall incidence of malignancy ranging from 3\% to $19 \%$
$(1,4,5)$. The overall rate of malignancy in our population was $20 \%$. The reported risk of malignancy in children with mediastinal masses is between $27 \%$ and $76 \%$ (9-11). Our incidence of malignancy in children was $61.5 \%$. In adults, most of the tumours are described as benign $(2,4,12)$. In our patients, the malignancy rate in adults was $8.5 \%$, which is similar to that of other reports $(8,12)$.

The diagnosis of MNT is most often established by CT and is now routinely performed in these patients. A preoperative diagnosis was established successfully in all of our patients with the help of tomography. CT scans provide information on the topography of the tumour and the presence of calcification, but may ignore an intraspinal extension. MRI is superior in this regard and should be performed when the tumour is suspected to extend into the spinal canal, to determine the longitudinal extent of the lesion within the canal.

The treatment of choice in most of the neurogenic tumours is complete resection. Complete resection is important to achieve satisfactory long term survival. We prefer the thoracotomy approach because this technique permits total excision of the tumour mass in most patients, even in large lesions (6). However, videothoracoscopic excision was reported to be a good alternative in some series in selected patients (2). The preferred mode of sugery is posterolateral thoracotomy in most patients. Tumours with dumbbell intraspinal extension may be excised by combined neurosurgical and thoracic procedures (13). Surgical resection of the tumour was complete in 56 of 60 patients $(93.3 \%)$ in our series. Resection of malignant tumours was grossly incomplete in four patients (33.3\%). All benign tumours were excised totally. The recurrence rate was three of 56 (5.3\%) in patients who had a complete resection initially.

Schwannomas, the most frequent neurogenic tumours of the mediastinum, are usually benign and cured by surgical excision $(2,8)$. Malignant transformation of a pre-existing schwannoma is very rare (14), and recurrence is uncommon (8). On the other hand, malignant schwannomas, which account for only $0.5 \%$ to $7 \%$ of all malignant neoplasms in this area, are agressive neoplasms and tend to recur locally and metastasize to the lung and the other organs $(8,15,16)$. Some investigators report that malignant schwannomas comprised $13 \%$ to $20 \%$ of all mediastinal schwannomas (17). In our practice, total excision of the tumour was successful in all benign schwannomas and no recurrence was detected. There were three malignant schwannomas among our patients and these consititute $9 \%$ of all schwannomas. One of the malignant schwannomas was in association with neurofibromatosis and complete resection was possible with no recurrence after the operation, although recurrence and metastasis are reported to be more common in patients with neurofibromatosis $(17,18)$.

Neurofibromas are the second most frequent neurogenic tumours of the mediastinum, where they occur as isolated neoplasms or as multiple thoracic manifestations of neurofibromatosis $(8,19)$. The frequency of neurofibromas in our population was $18 \%$ and there was a predominance in females, although in most of the previous studies, there was no sex predilection (8). The preferred mode of therapy is total 
excision of the tumour. We were able to resect the tumour totally in all patients.

MNT, when associated with von Recklinghausen's disease (neurofibromatosis), can be inherited and multifocal. In some series, as many as $14 \%$ to $30 \%$ of patients with mediastinal neurofibromas had neurofibromatosis $(8,12)$, and they usually present at a younger age and are at increased risk for malignant transformation. The malignancy rates are reported to reach $30 \%$ in these patients $(18,20,21)$. However malignant transformation of a pre-existing schwannoma is rare (14). In our patient population, only three tumours were associated with von Recklinghausen's disease. Although up to $29 \%$ of patients with neurofibromatosis have been reported to develop neurogenic sarcomas (17). Benjamin et al (22) reported two sarcomas in five neurofibromas with neurofibromatosis, and Oosterwijk et al (23) reported one sarcoma in three. In the present study, there were recurrences in both patients with neurofibromas associated with neurofibromatosis after initial complete resection, but no patients showed malignant transformation.

The automnomic ganglion cell tumours are rare neoplasms in a 'a biological continuum' from benign ganglioneuroma through low grade malignant ganglioneuroblastoma to highly malignant neuroblastoma $(8,24-26)$. Tumours with spinal extension should be resected with combined neurosurgical and thoracic procedures (13). Two of the ganglioneuromas and one of the malignant schwannomas had spinal invasion in the present study. Identification of intraspinal extension of the tumour by MRI is mandatory in such cases. Laminectomy was performed first and thoracic procedure followed immediately. The goal of the surgical intervention should be to prevent, mimimize and perhaps reverse those defects associated with cord compression. Enzinger and Wiess (17) have described rare instances of malignant transformation of ganglioneuromas to malignant schwannomas, but none of our patients showed this transformation. Neuroblastomas, which are highly malignant tumours, usually arise from adrenal glands, but may originate in extra-adrenal sympathetic ganglia; they involve the mediastinum in $16 \%$ of patients, accounting for approximetely $6 \%$ of all mediastinal neurogenic tumours (24,27-30). Half of these patients are younger than two years of age, and some of the tumours may be congenital.

\section{CONCLUSIONS}

The present study reports the clinical spectrum of MNT in a relatively large population. We conclude that the treatment of neurogenic tumours of the mediastinum should be based on their surgical excision. A combined neurosurgical and thoracic procedure is recommended for the excision of those with intraspinal extension. Complete resection is important to achieve satisfactory long term survival and can be performed successfully by a thoracotomy approach in most of the patients, with few complications and relatively low incidence of recurrence.

\section{REFERENCES}

1. Davis RD, Oldham HN, Sabiston DC. Primary cysts and neoplasms of the mediastinum: recent changes in clinical presentation, methods of diagnosis, management and results. Ann Thorac Surg 1987;44:229-37.

2. Bousamra M, Haasler BG, Patterson GA, Roper LC. A comparative study of thoracoscopic versus open removal of benign neurogenic mediastinal tumours. Chest 1996;109:1461-5.

3. Azarow KS, Pearl RH, Zurcher R, et al. Primary mediastinal masses. J Thorac Cardiovasc Surg 1993;106;67-72.

4. Davidson KG, Walbaum PR, McCormack RJM. Intrathoracic neural tumours. Thorax 1978;33;359-67.

5. Ribet ME, Cardot GR. Neurogenic tumours of the thorax. Ann Thorac Surg 1994;58;1091-5.

6. Bacha EA, Chapelier AR, Macchiarini P, Fadel E, Dartevelle PG. Surgery for invasive primary mediastinal tumours. Ann Thorac Surg 1998;66;234-9.

7. Harjula A, Mattila S, Luosta R, Kostiainen S, Mattile I. Mediastinal neurogenic tumours. Scand J Thorac Cardiovasc Surg 1986;20;115-8

8. Strollo DC, Rosado de Christenson ML, Jett JR. Primary mediastinal tumours. Part II. Tumours of the middle and posterior mediastinum. Chest 1997;112;1344-57.

9. Pokorny WJ, Sherman JO. Mediastinal masses in infants and children. J Thorac Cardiovasc Surg 1974;68;869-75.

10. Grosfeld JL, Bachner RL. Neuroblastoma: an analysis of 160 cases. World J Surg 1980;4;29-34.

11. Grosfeld JC, Bachner RL. Primary malignant neoplasms in infants and children. Ann Thorac Surg 1971;12:79-187.

12. Reed JC, Hallet KK, Feigin DS. Neural tumours of the thorax. Subject review from the AFIP. Radiology 1978;126:9-17.

13. Grillo HC, Ojenan RG, Scannel GJ, et al. Combined approach to "dumbbell" intrathoracic and intraspinal neurogenic tumours. Ann Thorac Surg 1983;36:402-7.

14. Thomas JE, Piepgras DG, Scheithauer B, et al. Neurogenic tumours of the sciatic nerve. Mayo Clin Proc 1983;58:640-47.

15. Ducatman BS, Scheithauer BW, Piepgras DG, et al. Malignant peripheral nerve sheath tumours: a clinicopathological study of 120 cases. Cancer 1986;57:2006-21.

16. Ghosh BC, Ghosh L, Huvos AG, et al. Malignant schwannoma. Cancer 1973;31:184-90.

17. Enzinger FM, Weiss SW. Soft tissue tumours. 2nd edn. St Louis: CV Mosby, 1988

18. Aughenbaugh GL. Thoracic manifestations of neurocutaneous diseases. Radiol Clin North Am 1984;22:741-56.

19. Chalmers AH, Armstrong P. Plexiform mediastinal neurofibromas. Br J Radiol 1977;50:215-7.

20. Hope DG, Mulvihill JJ. Malignancy in neurofibromatosis. Adv Neurol 1981;29:33-56.

21. Martin G, Kleinasser O. Neurogenic sarcomas of the neck in neurofibromatosis. Arc Otorhinolaryngol 1981;232;273-83.

22. Benjamin SP, McCormack LJ, Effler DB. Primary tumours of the mediasyinum. Chest 1972;62:297-303.

23. Oosterwijk WM, Swierenga J. Neurogenic tumours with an intrathoracic localization. Thorax 1968;23:374-84.

24. Gale AW, Jelihovsy T, Grant AF, et al. Neurogenic tumours of the mediastinum. Ann Thorac Surg 1974;17:434-43.

25. Pascaud JL, Le Goff JJ, Pascoud E, et al. Thoracic ganglioneuroma with intraspinal prolongations in childhood. Pediatr Radiol 1980;9:109-0.

26. Adam A, Hochholzer L. Ganglioneuroblastoma of the posterior mediastinum:a clinicopathological review of 80 cases. Cancer 1981;47:373-81.

27. Davis S, Rogers MAM, Pendergrass, TW. The incidance and epidemiologic characteristics of neuroblastoma in the United States. Am J Epidemiol 1987;126:1063-74.

28. Shimada H, Chatten J, Newton WA, et al. Histopathologic prognostic factors in neuroblastic tumours: definition of subtypes of ganglioneuroblastoma and age linked classification of neuroblastoma. J Natl Cancer Inst 1984;73:405-16.

29. Evans AE, D’Angio GJ, Propert M, et al. Prognostic factors in neuroblastoma. Cancer 1987;59:1853-60.

30. Carlsen NLT, Christensen IJ, Schroder H, et al. Prognostic factors in neuroblastoma treated in Denmark from 1943 to 1980. Cancer 1986;58:2726-35 


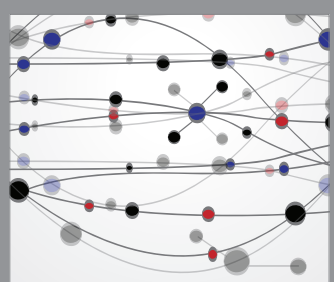

The Scientific World Journal
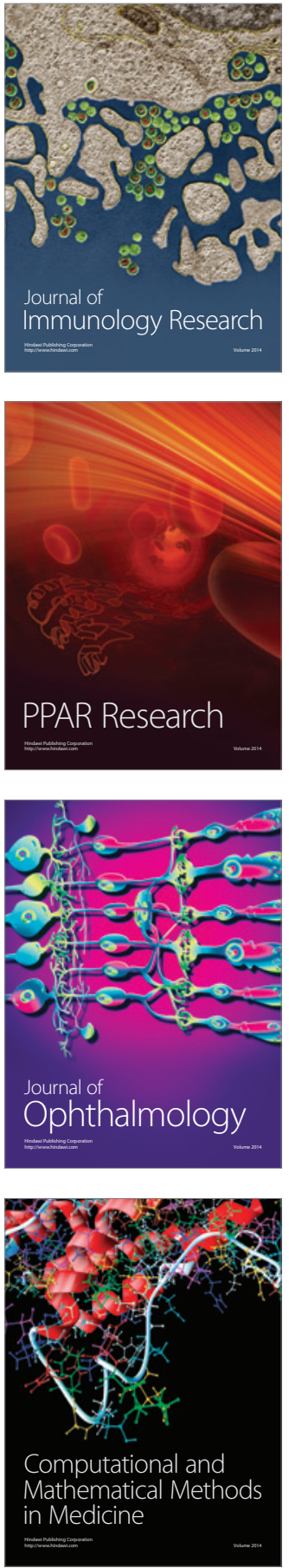

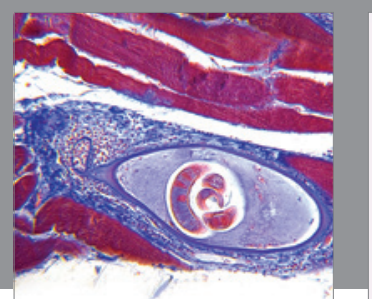

Gastroenterology Research and Practice

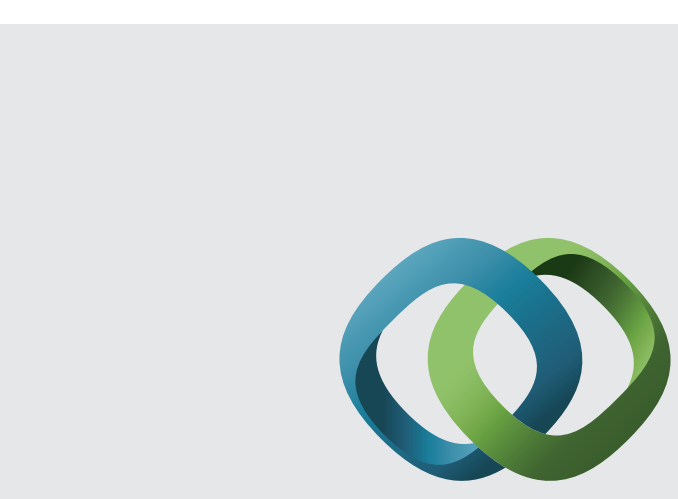

\section{Hindawi}

Submit your manuscripts at

http://www.hindawi.com
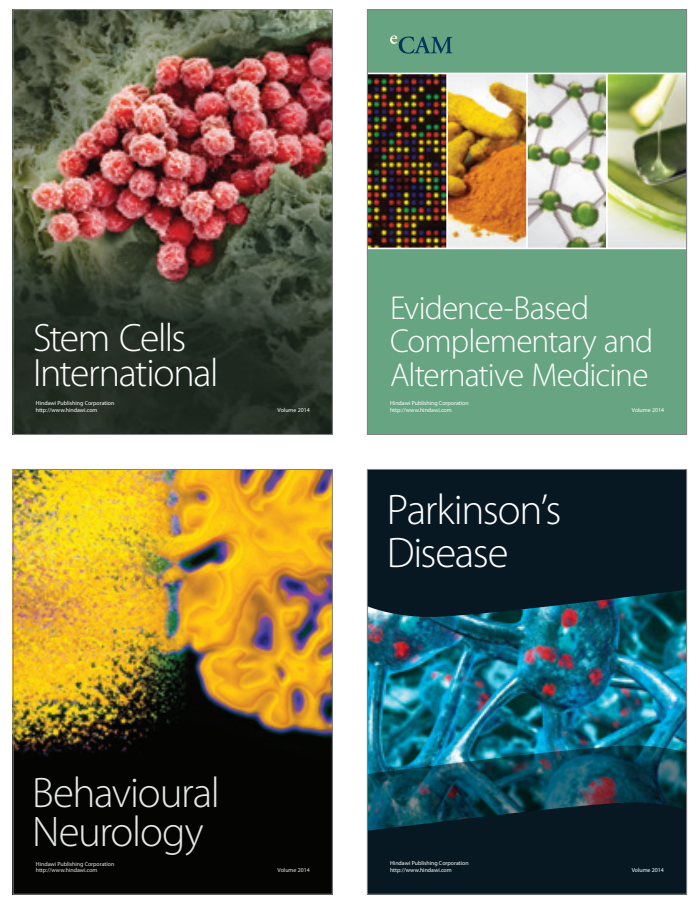
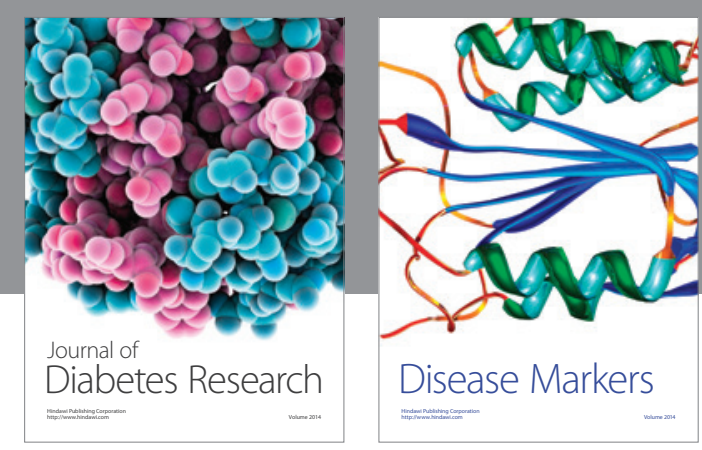

Disease Markers
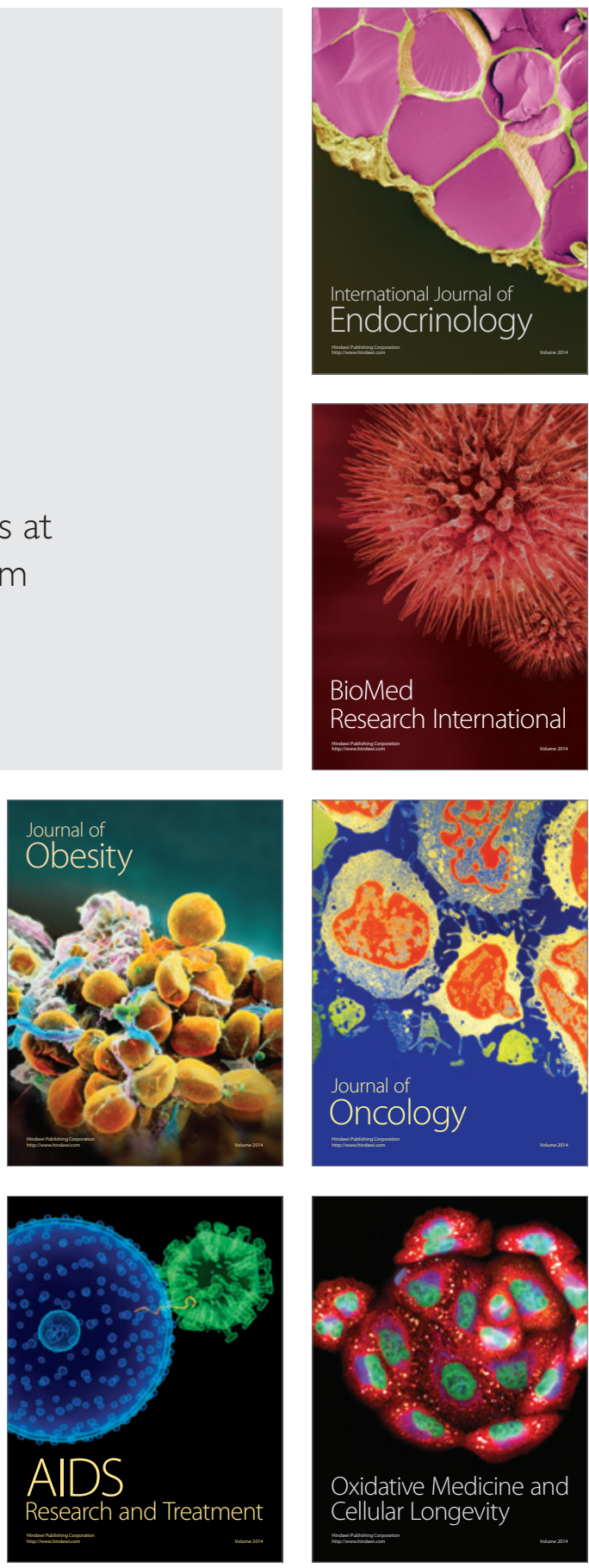